\title{
Water Conflicts in the Middle East and Africa: The Study on Efforts to Find Based Solutions Regional Cooperation Framework
}

\author{
Ryantori $^{1}$ \\ \{ryantori@dsn.moestopo.ac.id\} \\ Universitas Prof Dr Moestopo (Beragama) ${ }^{1}$
}

\begin{abstract}
This paper discusses the availability of water in the Middle East and Africa where this problem is a regional problem. This research is a qualitative research that uses several combined ideas as a reference. This research is descriptive which aims to describe how the security concept is applied by Israel in dealing with the problem of Palestinian refugees. This research will use a qualitative approach. The characteristic of water that crosses administrative and political boundaries is a trigger for regional water conflicts. The water conflict will then trigger other conflicts, such as economic and political conflicts between disputing areas that lead to regional instability.
\end{abstract}

Keywords: Water Conflicts, Cooperation Framework, Regional.

\section{Introduction}

Water is the source of all life on earth. Without water, no human and no animal can live, and neither can food be produced. Water also cannot be replaced by other objects. Unlike oil or other strategic resources, water cannot be replaced by any other good. However, currently clean water tends to be increasingly scarce. There are at least 130 million people in 80 countries who have suffered from acute water shortages. The number will also increase to one trillion by 2025 [1] [2]. The distribution of water is also carried out very unequally, both within one country and among different countries. There are 214 river basins that border between countries where two or more countries make use of their water flows. This is a potential source of conflict, but can also be a catalyst for international cooperation. Fortunately, at this time there is an interesting phenomenon in which about two thirds of the entire river area has cooperative management by the countries through which the river flows [1].

From a conflict perspective, water in the Middle East can become an object, tool, or conflict resolution if it is managed wisely by each country. Water becomes the object of conflict when countries between regions compete with each other, either by using military force or diplomacy to intervene and hegemony. If a country has a water source, or manages to control another country's water source, then water will become a tool of conflict. Because in that way the state that controls water sources is able to pressure other countries according to the interests it wants [2].

This shows that water has extraordinary strength. So it's no wonder that in 1995, World Bank Vice President Ismael Serageldin predicted that future wars would no longer be triggered by the struggle for black gold (oil), but by blue gold (water) [3]. 
The Middle East is one region that has acute problems related to the availability of water for daily needs. In fact, there have been some serious conflicts in this area related to water issues. Water can become a tool of conflict when it is used to suppress other countries. Call it the Nile which has an upstream in Ethiopia, then Ethiopia can use its power over water sources to suppress Egypt.

If Ethiopia does not want to pressure Egypt, Ethiopia can be used by other countries, as is happening now. The strong US and Israeli hegemony in the horn of Africa, coupled with the presence of Ethiopian Jews called "Beta Israel", made the Zionists increasingly determined to play their role in suppressing Egypt through Ethiopia. Because Israel asked Egypt to flow the waters of the Nile through the Sinai route to Israel. If Egypt does not fulfill Israel's request, the Zionist-Israel will intervene in Ethiopia so that it does not flow the Ethiopian Nile water to Egypt.

There is currently some research in place to build water dams in Ethiopia with the help of the World Bank. This activity is predicted to reduce $20 \%$ of the Nile water that will flow into Egypt, so that Egypt loses about 7 billion cubic meters of 55.5 billion cubic meters of water supply every year. Even to pressure Egypt, there is propaganda for Ethiopia to contain the entire blue Nile, so that it will form a huge lake in Ethiopia as a giant water store, then sell it to the country that wants it, just like selling oil.

Turkey also took advantage of the power of the upper Euphrates and Tiggris rivers to suppress downstream countries for its national interests. To that end, Turkey designed an Anatolian mega-project that included the construction of 25 irrigation systems, 22 dams on the Euphrates River line, and 19 power plants.

One of the 22 dams was built in 1990 under the name Attaturk dam. With the construction of this one dam alone, the water supply to Syria and Iraq has been reduced by $40 \%$ and $80 \%$, respectively. Moreover, if the other 21 dam projects are realized, it will certainly be a nightmare for Syria and Iraq. With the power of this upstream water power, Turkey once pressed Syria to eradicate the Kurdish rebellion in southern Turkey.

Water will also become the object of conflict when it is fought over. It is like Iraq and Syria fighting over the waters of the Euphrates river. The Syrians built a water dam on the Euphrates river for their domestic interests. Meanwhile, Iraq is trying to thwart the dam, to maintain adequate water supply to Iraq. This tension almost led to war between the two countries. So in 1974 and 1975, Iraq, as the loser, threatened to bomb the Syrian dam at Tabqa [4].

\section{Result and Discussion}

An important step forward in formulating a global water policy based on cooperation for cross-border water management between countries was held at a conference held in Petersberg near the City of Bonn, Germany, organized by the Development Policy Forum under the German Foundation for International. Development (DSE) collaborates with three German federation ministers for Foreign Affairs, Development Cooperation and Environment, and the World Bank. The Scholar notes that about 100 ministers, senior government officials and experts from Africa, Asia, the Middle East and Europe attended the conference and discussed and adopted the "Petersberg Declaration" which would not only serve as a guide for future German cooperation in water politics. , but it also influences international discussion on the issue [5].

Prior to adopting the declaration, the conference heard case studies of major international efforts to arrive at the opportunities and risks of transboundary river flows. Among the studies 
presented at the conference included the Rhine River, which flows through the different regions of the six European countries where 50 million people live and work. In the context of the river Rhine, it is presented as a very successful model for international cooperation going back to the commission formed in 1950. Cooperation on the Danube, the second largest river in Europe which flows through 13 countries in western, central and eastern Europe. Home to 82 million people, it is much more difficult to deal with because of European political differences [6].

This is also the case with the cooperation on the Mekong River, which is the twelfth largest river in the world and flows through six countries in Southeast Asia. Only four of these countries - Vietnam, Laos, Cambodia, and Thailand - agreed in 1995 to establish a Mekong River Commission for the fair and reasonable management and use of water, protect the river environment, safeguard mainstream flows, and ensure freedom of navigation. But Myanmar and China, where the river originates, have not joined the commission, and even China is planning or building ten dams for hydroelectric power on the riverbed further upstream, which will only create problems for countries that are on the riverbed. downstream area. Environmentalists have also seen the negative effects on fisheries of a large dam project in Laos where residents make a living from the river. But there are also competing interests of government and industry to take advantage of the availability of hydropower which in turn can complicate matters.

Scholars research reveals that there are more problems than successes in the Middle East region where warring parties over the Arab-Israeli conflict face additional problems that not only have to solve political and territorial problems, but must also agree on the need to share resources [7]. water that is getting very scarce. Cooperation between Israel and Jordan on the use of the Jordan and Yarmuk rivers has proceeded without friction, conference talks said. But Palestinians in the West Bank and Gaza Strip demand more equitable water from Israel which they perceive as unfair exploiting aquifers for their own benefit. Here as is possible in other cases it will not become clear how explosive the water problem can be if there is no genuine desire for composition and seeking a just solution.

The "Petersberg Declaration", which developed on the basis of views drawn from case studies and three days of discussion, emphasizes that a "common view" and a "shared vision" are essential for effective management of international water resources. Braue revealed that the declaration noted several important points including that, "solid political commitment and broad public support is essential for success" and that "broad partnerships that include participation by river countries, international financial institutions, development agencies bilateral and NGO "are very helpful in carrying out good cooperation.

The Declaration also prioritizes an "integrated approach" that links policy dialogue, structural reforms, use of economic instruments, technical interventions, environmental management and social concerns at various levels. The Declaration contains support for regional cooperation and an international watershed commission and emphasizes the merits of public-private partnerships in improving water services "in a cost effective, equitable, accountable and environmentally sustainable manner."

This, within the scope of the Middle East region, is then followed by efforts to seek regional water conflict resolution. Regional water conflict resolution is an effort to find solutions to inter-regional water disputes / conflicts to achieve an efficient and equitable level of water management. The very important keyword here is efficiency. This is because the inefficiencies that occur may reflect problems in the management and allocation of water resources in each region. The unclear property rights and efforts to transfer water rights to other areas are an obstacle to the cross-regional water management system. The determined 
water price has not shown the true value of water property rights which is analyzed using the total economic value approach, so that the water price often does not reflect the cost of conserving and protecting water resources.

Unfortunately, institutionally and culturally, the Middle East region, in terms of controlling water use efficiently in many regions, is still very weak, because water is still seen as a public good that is free to use indefinitely. This paradigm has led to scarcity of water quantity and quality. Therefore, with the increasing scarcity of water, it is increasingly important to implement economic instruments integrated with a socio-cultural approach to ensure a more efficient and equitable use of water resources across regions. Effective trans-regional water conflict resolution requires prior political resolution among the disputing territories and is carried out through negotiation and diplomacy processes. The parties involved need to raise the issue of how to share, develop (to develop) and manage (to manage) increasingly limited cross-regional water resources by taking into account physical, biological, social, economic, cultural (ethnic) characteristics. along the disputed watercourse. The negotiation process was carried out to find a more efficient and equitable water distribution mechanism for the areas in the river water flow.

An interesting phenomenon is the existence of Egypt which, from a geographic perspective, can be included in both the Middle East and the African region. Plus, Egypt is one of the important countries in the two regions. Seeing its potential, Egypt can be an important determinant of water problems in the two regions.

And that is what Egypt did. One of the efforts being tried in relation to the above is between Egypt and Ethiopia in finding a joint mechanism for managing the flow of the Nile river. This is mainly because the headwaters of the Nile are located in the high mountainous region of Ethiopia. There the water temperature is much cooler, and the water stored in deep reservoirs is used to generate electric power. This water barely evaporates. Meanwhile, agricultural land requires a lot of river water. Plants suck water through their roots and let it evaporate through their leaves.

Therefore it is more profitable for Egypt if they cooperate with a number of hydropower plants in Ethiopia to generate electricity, rather than trying to build their own hydropower project through a giant project, the Aswan Reservoir. The Aswan River is located in an area where the temperature is much hotter, not so deep and the water level of this river is also very wide. Nearly 10 percent of the Nile's precious water lost is evaporated in this way [8].

A good agreement between the countries that flow through the Nile could save a large amount of water, so countries that are currently not benefiting can feel it too.

If the potential for cooperation can also occur between Egypt and Uganda. Egypt needs 7000 cubic meters of water to irrigate one hectare of corn fields. But the same amount of water could irrigate 10 hectares of cropland in Uganda. If the two countries cooperate, for example using the expertise of Egyptian agricultural experts, then the benefits obtained can be multiplied or more. This cooperation could be further enhanced by involving Rwanda, Tanzania and Kenya along the Nile River.

Various agreements in cross-regional water management need to be supported by a clear institutional framework, such as strengthening legal (environmental) instruments, strengthening government capacity in water management, and using economic instruments. Cross-regional water management must be carried out in an integrated, comprehensive, and interdisciplinary manner which involves various potential areas to manage water better and efficiently. According to Scholar, there are several things that need to be developed towards sustainable cross-regional water management [9], namely: 
a. The principle of benefit sharing is more important than water sharing alone. It needs to be understood and applied to make water a catalyst for inter-regional development cooperation as an effort to avoid water conflicts.

b. Defines rights-hWater property rights are clearly part of the process of negotiation, bargaining, and more efficient allocation of water sources.

c. Promote more efficient use of water.

d. Use of incentives to increase cost efficiency in collaborative cross-regional water management programs.

e. Exchange of knowledge and information between regions involved in cross-regional water management.

f. Strengthen cooperation and development linkages between upstream and downstream rivers as part of an integrated watershed management system.

If linked with the results of the "Petersberg Declaration", it is hoped that the framework for overcoming water conflicts in the Middle East can run optimistically. It should be emphasized that in order for any effort to create a framework for resolving water conflicts to run well, based on the Petersberg Declaration in 1998, there are several important factors that must be done, namely:

a. Shared Vision (Vision to share). Each region needs to have a desire to share in utilizing water, including sharing in information exchange and more efficient water management technology.

b. Political commitment and public support from each region to create an efficient and equitable (fair) water distribution system. Strong commitment among stakeholders becomes the normative basis for cross-regional water management.

c. Broad Based Parternships (broad partnership) between the government, legislature, universities, non-governmental organizations, and other community groups as a form of participation in water management.

d. Environmental Management (environmental management) must be integrated into crossregional water management. Tools in environmental management such as environmental impact analysis, evaluation of water quantity and quality, etc. will ensure ecosystems and conservation along river basins. The next stage after negotiations is to determine the crossregional water allocation mechanism that will be implemented. The water allocation mechanism should be based on water property rights which can be clearly defined and agreed upon by each region. Scholar proposes the use of economic instruments to regulate the crossregional water allocation system, such as the implementation of a water market mechanism that ensures more efficient use of water resources [4].

Compared to the Middle East region, the African region can be said to have gone one step further in developing a regionalism mechanism. Historically, it was preceded by the idea of forming the Organization of African Union (OAU). This idea cannot be separated from the idea of Pan-Africanism which wants a large entity in order to unite African nations so that they can compete with the progress that has been achieved in other regions as stated in the 2004 African Union Commission. The unity of all African countries is the main basis for reduce a number of conflicts and disputes that continue to occur continuously and create a stable area that supports more advanced development strategies and plans. Therefore, through this OAU framework, African countries seek to realize a more modern Africa with significant progress in achieving regional integration. Efforts to achieve regional integration have been realized through various instruments [10]. 
In 1964 a commission for mediation, conciliation and arbitration was formed as a mechanism for resolving conflicts that occurred in the region. And the commission was strengthened when in 1993 a declaration on conflict prevention, management and resolution was issued. In fact, in 2000 the declaration on regional security and stability was triggered to create stability and improve the climate for cooperation between African countries. However, the efforts made by the OAU to create a stable region that can promote regional integration have not been fully achieved because a number of conflicts both domestic and between countries still occur.

When the OAU evolves into the African Union (UA) there is optimism that this new regional cooperation framework will provide a strong binding power for cooperation between African countries. This is based on the form of Union which is a high stage of the regional integration process of a region. Moreover, if you review the African Union Constitutive Act, it can be concluded that this organizational framework is almost similar to the European Union, where the African Union's organizational organs comprise the Upper House; Executive Council; Pan-African Parliament; African Court; Commission; Permanent Representative Committee; Special Technical Committee; Economic, Social and Cultural Council; Peace and Security Council; and Financial Institutions (African Union Web Site, www.africa-union.org). With this new form, the African Union wants to become a regional organization as progressive as the European Union has achieved i more advanced stages of regional integration. However, the regional internal conflict dimension cannot be separated from the effectiveness of this organization in achieving regional integration that unites and integrates Africa (united and integrated Africa) by 2030.

Of course, one important breakthrough that is awaited is the ability to find effective and effective mechanisms to solve any problems related to water sharing in every corner of Africa now and in the future.

\section{Conclusion}

The characteristic of water that crosses administrative and political boundaries is a trigger for regional water conflicts. The water conflict will then trigger other conflicts, such as economic and political conflicts between disputing regions that lead to regional instability. Therefore water is no longer a free public good, but water has shifted into an economic commodity, a political tool, and a weapon of mass destruction between regions. Regional water conflict resolution must be based on considerations to use and allocate water resources efficiently and fairly, and be supported by a unified vision for sharing, political commitment and political support, partnership and public participation, and applying the principles of sustainable environmental management.

As a region that is indeed poor with water availability, the Middle East and Africa region is currently trying to find the right cooperation framework so that the water problem, which has so far turned into a regional conflict, can be resolved properly - although this must be obtained through how to learn from other regions. 
This regional cooperation framework is one of the interesting topics in the study of contemporary international relations in the midst of the rampant phenomenon of conflict with its various variations. The process of finding this mechanism seems an inevitable necessity so that water that has had a negative connotation, such as conflict over water or even water wars, as Vandhana Shiva is concerned, can turn into a positive connotation, into a peace tool in the form of cooperation in water management for the benefit of all. stakeholders.

\section{References}

[1] H. Haftendorn, "Water and international conflict," Third World Q., 1999.

[2] W. R. Ginanjar and A. Z. Mubarrok, "Civil Society and Global Governance: The Indirect Participation of Extinction Rebellion in Global Governance on Climate Change," J. Contemp. Gov. Public Policy, vol. 1, no. 1, pp. 41-52, 2020.

[3] I. Berman and P. M. Wihbey, "The New Water Politics Of The Middle East," 1999.

[4] A. Siddiqi and L. D. Anadon, "The water-energy nexus in Middle East and North Africa," Energy Policy, 2011.

[5] J. Sowers, A. Vengosh, and E. Weinthal, "Climate change, water resources, and the politics of adaptation in the Middle East and North Africa," Clim. Change, 2011.

[6] A. T. Wolf, "Shared waters: Conflict and cooperation," Annu. Rev. Environ. Resour., 2007.

[7] T. Allan and N. Kliot, "Water Resources and Conflict in the Middle East," Geogr. J., 1994.

[8] R. A. Adler, M. Claassen, L. Godfrey, and A. R. Turton, "Water, mining, and waste: An historical and economic perspective on conflict management in South Africa," Econ. Peace Secur. J., 2007.

[9] E. M. Biggs et al., "Sustainable development and the water-energy-food nexus: A perspective on livelihoods," Environ. Sci. Policy, 2015.

[10] P. H. Gleick, "Water, drought, climate change, and conflict in Syria," Weather. Clim. Soc., 2014. 